Meta

Journal des traducteurs

Translators' Journal

\title{
Musicality and Intrafamily Translation: With Reference to European Languages and Chinese
}

\section{Laurence Wong}

Volume 51, numéro 1, mars 2006

URI : https://id.erudit.org/iderudit/012995ar

DOI : https://doi.org/10.7202/012995ar

Aller au sommaire du numéro

Éditeur(s)

Les Presses de l'Université de Montréal

ISSN

0026-0452 (imprimé)

1492-1421 (numérique)

Découvrir la revue

Citer cet article

Wong, L. (2006). Musicality and Intrafamily Translation: With Reference to European Languages and Chinese. Meta, 51(1), 89-97.

https://doi.org/10.7202/012995ar
Résumé de l'article

La plupart des traducteurs conviennent que la traduction est au mieux un ersatz qui ne permet de transmettre qu'une partie du sens du texte source, soit sur deux niveaux : sémantique et phonologique. Ils sont déjà conscients de ce qui manque dans la traduction d'un lexème, que dire alors des longues phrases d'un texte. Sur le plan sémantique, par exemple, la dénotation d'un lexème peut parfois être conservée presque intacte. Cependant, les connotations du lexème, ses associations et nuances, qui peuvent faire surgir des réponses subtiles des lecteurs de l'original, défient souvent le processus du transfert Cependant, comparé à la musicalité, trait de niveau phonologique, tous les traits du niveau sémantique deviennent relativement faciles à rendre. En s'appuyant sur des traductions de la Divine comédie de Dante en espagnol, en français, en latin, en anglais, en allemand et en chinois, ainsi que sur la traduction de Macbeth de Shakespeare en italien, l'article traite de musicalité, soit le trait le plus récalcitrant des traits du texte de la langue source et démontre, en fonction de facteurs à examiner en détails, que des traductions dans les langues parentes peuvent saisir la musique originelle à un degré de succès variable.
Ce document est protégé par la loi sur le droit d'auteur. L'utilisation des services d’Érudit (y compris la reproduction) est assujettie à sa politique d'utilisation que vous pouvez consulter en ligne.

https://apropos.erudit.org/fr/usagers/politique-dutilisation/ 


\title{
Musicality and Intrafamily Translation: With Reference to European Languages and Chinese
}

\author{
LAURENCE WONG \\ Lingnan University, Tuen Mun, Hong Kong \\ wongkp@ln.edu.hk
}

\begin{abstract}
RÉSUMÉ
La plupart des traducteurs conviennent que la traduction est au mieux un ersatz qui ne permet de transmettre qu'une partie du sens du texte source, soit sur deux niveaux: sémantique et phonologique. Ils sont déjà conscients de ce qui manque dans la traduction d'un lexème, que dire alors des longues phrases d'un texte. Sur le plan sémantique, par exemple, la dénotation d'un lexème peut parfois être conservée presque intacte. Cependant, les connotations du lexème, ses associations et nuances, qui peuvent faire surgir des réponses subtiles des lecteurs de l'original, défient souvent le processus du transfert. Cependant, comparé à la musicalité, trait de niveau phonologique, tous les traits du niveau sémantique deviennent relativement faciles à rendre. En s'appuyant sur des traductions de la Divine comédie de Dante en espagnol, en français, en latin, en anglais, en allemand et en chinois, ainsi que sur la traduction de Macbeth de Shakespeare en italien, l'article traite de musicalité, soit le trait le plus récalcitrant des traits du texte de la langue source et démontre, en fonction de facteurs à examiner en détails, que des traductions dans les langues parentes peuvent saisir la musique originelle à un degré de succès variable.
\end{abstract}

\begin{abstract}
Most practitioners of translation agree that translation is at best an ersatz, able to get across only part of the source text's meaning, which is meaning on two levels: the semantic and the phonological. Even in translating an apparently simple lexical item, to say nothing of long stretches of discourse, they are keenly aware of what is being left out. On the semantic level, for example, the denotation of a lexical item may sometimes be preserved almost intact. However, its connotations, associations, or nuances, which can elicit subtle responses from readers of the original, often defy the process of carrying over or across, which is what transferre, the Latin word from which translate is derived, means. Yet, compared with musicality, a feature on the phonological level, all features on the semantic level will become relatively easy. With reference to translations of Dante's Divine Comedy in Spanish, French, Latin, English, German, and Chinese, as well as translations of Shakespeare's Macbeth in Italian, this paper discusses musicality as the most recalcitrant of all features in a source-language text, and attempts to show how, depending on factors to be examined in detail, intrafamily translation, that is, translation between languages of the same family, can capture the original music with varying degrees of success.
\end{abstract}

\section{MOTS-CLÉS/KEYWORDS}

musicality, intrafamily, semantic, phonological, transferre

When practitioners and theorists of translation talk about translatability or untranslatability, what is uppermost in their minds is often the semantic level. They generally agree that, while the denotations of the original readily lend themselves to the process

Meta LI, 1, 2006 
of "carrying over or across," which is the meaning of transferre ("to carry over or across"), the Latin word from which the English translate is derived (Simpson 1968: 611), connotations, associations, and nuances relating to the semantic level prove more elusive. Yet, compared with musicality, all semantic features are easy fare.

By "musicality," I mean phonological features that contribute to the sum total of the original's meaning. It can be "music" in the conventional sense of the word, with all those qualities associated with what is the mellifluous, melodious, or pleasing to the ear; at the same time, it can encompass phonological features that are deliberately cacophonic or discordant, employed by the addresser to get his message across more effectively, more memorably, or with greater emphasis. When a Frenchman says, "Quand on est cantonais, on est né à Canton" (literally "When one is Contonese, one was born in Canton," meaning "Cantonese were born in Canton"), the communication of the message depends as much on the echoing of the same sounds in "Quand on est cantonais, on est né...canton" as on the signifiés of the individual lexical items on the semantic level. When the target language has no corresponding phonological items to reproduce the same effect, the translation cannot be considered to have adequately carried over the total meaning of the message. Similarly, when a Spaniard says, "Del dicho al hecho hay mucho trecho" (literally "From the word to the deed, there is much distance," meaning "Its is easier said than done"), a large part of the meaning is conveyed by the interplay of phonological features, such as the repetition of the vowels " $e$ " and " $o$ " and of the voiceless post-aveolar affricate "-ch-" (/t $\left.\int /\right)$, which requires more physical effort on the part of the addresser when making the utterance, suggesting strenuousness and conditioning the addresser in such a way that he is compelled, through kinaesthesia, to feel the distance ("trecho") between the "word" ("dicho") and the "deed" ("hecho"). In the English translation, there are no such phonological features. Saying it aloud without much physical effort, one is aware of a suggestiveness opposite to that of the original: instead of feeling "much distance" ("mucho trecho"), one feels "little distance" ("poco trecho").

With respect to the significance of phonological features in the communication of a message, Italian can perhaps provide us with the largest number of everyday examples. Thumb through an Italian dictionary, and we will find saying after saying in which the communication of the message depends heavily - or even hinges - on phonological features: "Poca brigata, vita beata" (literally "Fewer people, blessed life," meaning "Small company makes for happy life"); "Patti chiari, amici cari" (literally "Clear agreement, dear friends," meaning "Terms clearly defined in advance prevents quarrels later"); "Cielo a pecorelle, acqua a catinelle" (literally "A sky with fleeces, water in washhand basins," meaning "A sky with fleece-clouds forebodes plenty of rain, that is, raining cats and dogs"); "Moglie e buoi dei paesi tuoi" (literally "Wife and oxen of your hometown," meaning "If you must marry, marry a woman of your hometown"); "Aprile, dolce dormire"(literally "April, sweet sleep," meaning "In April, one sleeps best"); "Il soverchio rompe il coperchio" (literally "Excess breaks the cover," meaning "Excess is harmful"); "Chi di spada ferisce, di spada perisce" (He who hurts with the sword dies by the sword); "Casa mia, casa mia, per piccina che tu sia, tu mi sembri una badia" (literally "My home, my home, small as you are, to me you seem an abbey," meaning "Home, sweet home").... With a master translator, it may be possible to reproduce in the target language certain phonological features approximating those 
of the original; yet, no matter how ingenious the translator is, the success is bound to be partial because no two languages are phonologically identical.

For this reason, therefore, of all the problems posed by a source-language text, musicality is certainly one of the most recalcitrant - perhaps the most recalcitrant - a translator has to face. When the writer of the source-language text confines himself to linguistic devices on the semantic level, translation can be relatively easy; when he draws heavily on phonological features of the language with which he is working, especially in longer stretches of discourse, the abilities of the translator can be taxed to the full. With masters of language like Dante and Shakespeare, the problem can border on the completely insurmountable. Take the following passage from Dante's Divine Comedy, for example:

A l'alta fantasia qui mancb possa; ma già volgeva il mio disio e il velle, sì come rota ch'igualmente è mossa,

l'amor che move il sole e l'altre stelle. (Dante 1960: 798)

As the climax and concluding lines of the Italian masterpiece, the quotation works powerfully not only on the semantic level, but also on the phonological level, making full use of the interplay of vowels ( $a$, , " $i$, , " $o$," " $e$ "), especially in the last line, where " $a$," " $o$," and " $e$ " set off a pleasing resonation, echoing one another in a rich, mellifluous pattern of sounds that drives home through its suggestiveness the harmony which the Pilgrim has reached with the Holy Trinity in the Empyrean.

For a translator, this kind of musicality, which is musicality of the first order, is the most formidable, ${ }^{1}$ especially in respect of interfamily translation, that is, translation between two different language families, such as the Indo-European and the Sino-Tibetan. In translating the four lines quoted above into Chinese, I have retained Dante's terza rima, and re-created a metre of my own to complement what is conveyed by the semantic signifiés in the original:

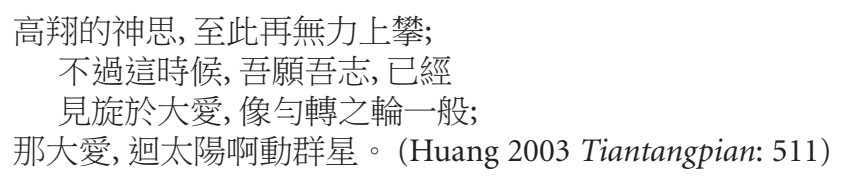

However, because of the vast gap between Italian and Chinese, which belongs respectively to the Indo-European and the Sino-Tibetan family, a large part of the original's musicality is lost beyond redemption, particularly with respect to the last line of the translation, in which one can no longer hear the satisfying echoing of the vowels so consummately deployed by Dante.

Moving from interfamily to intrafamily translation, one will see the linguistic gap narrowing:

Here force failed my high fantasy; but my

desire and will were moved already - like

a wheel revolving uniformly - by

the Love that moves the sun and the other stars. (Mandelbaum Paradiso 1984: 303)

In the English translation, one can hear an echo, albeit faint and remote, of the original's music in "fantasy" (for "fantasia"), "will" (for "velle"), "were moved" (for "move"), "revolving" (for "mossa," but echoing "volgeva"), and "stars" (for "stelle"), 
which become more audible when played against the frequency of Chinese. However, compared with those members of the same family that have a closer affinity with Italian, English is still not too competent a "performer." This is because English is still one or two degrees removed from Italian: while Italian belongs to the Italic branch, English belongs to the German.

For the same reason, German, another member of the German branch, fares no better:

Der hohen fantasein brach hie verträuen:

Doch schon bewog mein $>$ sehnen $<$ und mein $>$ gerne $<$

Rade geleich, das rollt auf bahnen neuen:

Minne, di wiegt die sonne und andern sterne. (Borchardt 1967: 467)

To be sure, one can hear a faint echo of the original in "fantaseîn" (for "fantasia") "sonne" (for "sole"), and "sterne" (for "stelle"), but the grating "brach," "doch," "geleich," and, particularly, the guttural "rade" (for "rota") have all but destroyed the original's mellifluousness and harmony.

By looking closely at the German version, one can see that the "infelicitousness" is due not to some personal failing on Borchardt's part; working within the "limitations" of German, ${ }^{2}$ Borchardt has proved to be a competent translator. However, because of the great difference between the German and Italian phonological systems, the translator has no alternative but to make the best of an impossible job. This point will be better illustrated if we look at another German version of the same lines:

Die hohe Bildkraft mußte hier versagen,

Doch schon bewegte meinen Wunch und Willen,

So wie ein Rad in gleichender Bewegung

Die Liebe, die beweget Sonn und Sterne. (Gmelin 1949 Das Paradies: 401)

The harsh-sounding "Bilfkraft," "versagen," and "Rad," the voiced alveolar fricative /z/ in "versagen," "So," and "Sonn," the voiceless velar fricative /x/ in "Doch," the voiceless post-aveolar fricative / / in "schon," "Wunsch," "gleichender," and "Sterne," and the voiced labio-dental fricative /v/ in "Wunsch" and "Willen" all "conspire" effectively to "sabotage" the original melody. ${ }^{3}$ It is clear, then, that any inability on Borchardt's part to replay the original music is due to linguistic rather than personal factors.

When one enters the Italic branch, one's ears will immediately be greeted by less "alien" sounds, sounds in which one can recognize a closer kinship with Italian. Take Jacqueline Risset's French translation of the same lines:

Ici la haute fantaisie perdit sa puissance;

mais déjà il tournait mon désir et vouloir

tout comme roue également poussée,

l'amour qui meut le soleil et les autres étoiles. (Risset 1990 Le Paradis: 315)

In addition to "fantasie" (for "fantasia"), which plays more or less the same role as the English "fantasy" and the German "fantaseîn," "désir"(for "disio"), vouloir (for "velle”), "également" (for "igualmente"), "l'amour" (for "l'amor"), and "soleil" (for "sole") have moved much closer to the Italian music than do their counterparts in the English and German versions. With exactly the same pronunciation as its Italian counterpart " $e$ " $(/ \mathrm{e} /)$, the French conjunction " $e t$ " $(/ \mathrm{e} /)$ reminds the reader that he is listening to a 
gamut with a frequency not too dissimilar from that of the original. If one reads the English, German, and French versions aloud, one will also be aware that, as a whole, the French version is softer, more "feminine," and more in tune with the mood and condition to which Dante the Pilgrim has risen, due, no doubt, to the fact that both Italian and French are Romance languages descended from Latin.

Nevertheless, despite the more competent "performance" of French in replaying Dante's music, it is in Spanish and Latin that one finds the closest frequency to that of Dante's celestial music. Take a Spanish version of the four quoted lines:

Ya mi alta fantasía fué impotente; mas cual rueda que gira por sus huellas, el mío y su querer movió igualmente,

el amor que al sol mueve y las estrellas. (Mitre 1938: 307)

The similarity between Spanish and Italian can instantly be recognized even by someone who speaks neither language: "alta," "igualmente," and "amor" have the same spelling as their Italian counterparts; "fantasía" (for "fantasia”) and "mío" (for "mio") differ from the Italian words only in the presence of an accent; "movió," "sol," and "mueve," though spelt differently, can readily be linked to the Italian "move" and "sole." Because of this close kinship, the Spanish music is just as mellifluous and harmonious as the Italian original, suggesting with equal effectiveness the beatitude granted to Dante the Pilgrim, a state which is best described by the famous line spoken by Piccarda Donati in the sphere of the Moon: "E 'n la sua volondade è nostra pace" (Dante 1960: 690). ${ }^{4}$

To see whether the musicality reproduced by Mitre is accidental or due to some other factors, we can look at another version in the same language. Published in 1968, the Spanish version, in prose, is by Arce:

Pero a mi fantasía faltó fuerza; y ya deseo y voluntad giraban como rueda con uniformidad, impulsados por el Amor que mueve al sol y al las demás estrellas. (Arce 1968: 451)

Words like "pero," “a," “mi," “fantasía," “deseo," “voluntad," "giraban,” "como," “rueda," "uniformidad," "impulsados," "por," "el," "Amor," "que," “mueve”...readily remind the reader that he is listening to almost the same piece of music as the Divine Comedy. To those who read both German and Spanish, the word "rueda" (meaning "wheel," for the Italian "rota") is especially instructive: the gliding from " $u$ " to " $e$," which is highly mellifluous in the context, contrasts sharply with the German "Rad," which, being guttural and harsh, fails to fit in with the celestial music intended by Dante. Working with German, which has a phonetic pattern suited to a different kind of music, a translator rendering the last canto of the Paradiso has really very little room for manoeuvre. ${ }^{5}$ Working with Spanish, a translator has a phonological system made up of very similar musical notes as Dante's Italian; when he is called upon to sing the heavenly music of the last canto of the Paradiso, he will be able to rise to the challenge with little effort.

With Latin, the story is more or less the same, except that, while Spanish is related to Italian like one sibling to another, Latin is related to Italian like a father to his child. For this reason, one can expect to hear music of a frequency very similar to that of Italian when the great lines of the Paradiso are translated into Latin: 
Alte phantasie hic defecit posse;

Sed iam involvebat meum velle, [divinum] velle,

Sicut rota que equaliter movetur,

Amor qui movet solem et alias stellas. (Serravalle 1891: 1213)

Except for a few words like "hic" (here), "iam" (already), and "sicut" (just as), all the other words are either similar to or identical with their counterparts in the Italian original. As Latin is Italian's father, it is just natural to see in it the image of the son.

In the preceding paragraphs, the discussion has centred on Italian as the source language, which has made English and German appear to be incompetent candidates for the task of reproducing musicality. When the source language is English, we will see the situation reversed: in translating musicality in the English-Italian direction, it will be the turn of the Italian language to have its "inadequacies" exposed.

For the sake of a more objective comparison, let us look at the work of Shakespeare, a poet comparable to Dante in stature. ${ }^{6}$ In one of his great tragedies, Macbeth, the Bard of Avon has three witches prepare a charm with all sorts of horrid ingredients that can give the audience the creeps. The setting is a cavern. When the three witches enter, there is thunder, as is the case with Act 1, Scene 1, Act 1, Scene 3, and Act 3, Scene 5. The world evoked is the antipode of the Paradiso:

$\begin{array}{ll}\text { Second Witch. } & \text { Fillet of a fenny snake, } \\ \text { In the cauldron boil and bake; } \\ \text { Eye of newt, and toe of frog, } \\ \text { Wool of bat, and tongue of dog, } \\ \text { Adder's fork, and blind-worm's sting, } \\ \text { Lizard's leg, and howlet's wing, } \\ \text { For a charm of powerful trouble, } \\ \text { Like a hell-broth boil and bubble.... } \\ \text { Scale of dragon, tooth of wolf, } \\ \text { Third Witches' mummy, maw and gulf } \\ \text { Of the ravin'd salt-sea shark, } \\ \text { Root of hemlock digg'd i' the dark.... (Shakespeare 1974: 860) }\end{array}$

The moment they are spoken, these lines will start working simultaneously on two levels: the semantic and the phonological. On the semantic level, the signifiants will, through the signifiés, evoke a complex of images, associations, and connotations that complement and reinforce one another, thereby contributing to the eerie and bizarre atmosphere intended by Shakespeare. Phonologically, the sounds, from whole lines down to the single phoneme, co-operate to suggest what the semantic units are powerfully evoking. Take the sharp monosyllabic words "snake" (/sneIk/), "bake" (/berk/),

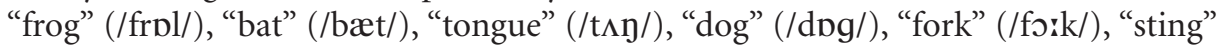
(/stin/), "leg" (/leg/), "shark" (/ Ja:k/), and "dark" (/dark/). Apart from the vowels, the velar plosives $/ \mathrm{k} /$ and $/ \mathrm{g} /$, the alveolar plosive $/ \mathrm{t} /$, and the velar nasal $/ \mathrm{g} /$, together with the strenuous "-zard" (/zəd/) in "lizard" (/'lizəd/), the explosive "b $\Lambda$ b-" (/bžb/) in

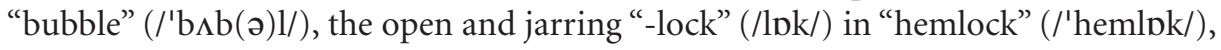
and the sharp, short "dig-" (/dig/) in "digg'd (/digd/), all help the audience "hear" the eerie, the bizarre, the mysterious, and the horrid; ${ }^{7}$ what was originally abstract has become something concrete, something clearly audible. In his The Four Quartets: Little Gidding," Eliot (1963: 221)) describes “every phrase / And sentence that is right" as one in which "every word is at home, /Taking its place to support the others, /...The 
complete consort dancing together." After listening to the quotation from Shakespeare, one is tempted to conclude that it must have been the kind of "phrase" and "sentence" Eliot had in mind when he was writing the above lines.

As the greatest English poet, Shakespeare is able to exploit the phonological system of the English language more skilfully than any other English poet. In writing the witches' lines, he must have had complete mastery of his tools, namely, all the sounds of the English language available to him. When called upon to translate the musicality created by these sounds into a language made up of a different phonological system, a translator may employ phonological features that appear to correspond to those of the original, using poetic devices common to both the source and target languages, such as rhyme and alliteration. ${ }^{8}$ However, since the target language is made up of a different phonological system, its "limitations" will immediately become obvious in the translation:

$\begin{array}{ll}\text { 2a STREGA } & \text { Bolli e cuoci nella pentola } \\ & \text { tu, filetto di serpente; } \\ & \text { ramarro occhiuto, pollici di rana, } \\ & \text { vampiro peloso e lingua di cane. } \\ & \text { Forca di serpe, aculeo d'orbetto } \\ & \text { zampe ed ali, ramarri e civette, } \\ & \text { magie potenti, gorgogli del male, } \\ & \text { bollite tutti nel brodo infernale... } \\ \text { 3a STREGA } & \text { Dente di lupo, dragone a scaglie, } \\ & \text { mummia di strega, gonfie frattaglie } \\ & \text { del pescecane d'acqua salata, } \\ & \text { cicuta al buio disradicata.... (Gassman, 1983: 92-93) }\end{array}$

In terms of sound effect, the Italian version makes a widely different impact on the listener: the rich pattern of vowels (" $o$," " $i$," " $u$," " $e$," and " $a$ ") resonates across the lines and echo one another in a music that is full and mellow, deviating drastically from Shakespeare's music: there is no longer the discordance that works in unison with the semantic level; ${ }^{9}$ the Stravinskian cacophony in the original has given way to a Mozartian harmony. While Mozartian harmony has its proper place in Canto 33 of Dante's Paradiso, with respect to the Macbeth scene, it is just too "beautiful."

From the above discussion, it can be seen that, in respect of musicality, intrafamily translation is much easier than interfamily translation. In interfamily translation, musicality of a different kind may be created by the translator's ingenious handling of a different phonological system, but it is no longer musicality of the same gamut, much less musicality of the same notes. When one moves from interfamily to intrafamily translation, a higher degree of phonic fidelity can be achieved: the closer the affinity, the higher the phonic fidelity. Within the same family of languages, it can be further seen that intrabranch translation, as is the case with Italian-Spanish translation, yields musicality of an even higher degree of phonic fidelity. Lastly, if one wishes to make even finer distinctions, one can say that, within the same branch, musicality lends itself most readily to translation between languages with the closest kinship, such as Italian and Spanish.

In Florence, there is a church called Santa Maria Novella. Even to one who is not a native speaker of Italian, the sound of the name gets across like a melody, working as it does on the interplay of a pleasing pattern of vowels. Say it in English: "New 
St. Mary” (/njui//sənt/ /'meəri/), or, worse still, in Chinese: “新聖瑪利亞(/cin//səy/ /ma/ /li//ia/), and the music vanishes into thin air. " "Così la neve al sol si disigilla; / cosi al vento ne le foglie levi / si perdea la sentenza di Sibilla" (Dante 1960: 796) - "Thus the snow loses its imprint in the sun; thus in the wind on the light leaves the Sibyl's oracle was lost" (Sinclair 1971: 481). Say it in Spanish: "Santa Maria Novela," and the music remains intact. In the light of this difference, therefore, translators working between languages that belong to two different families or branches can only hope to produce a musical ersatz.

\section{NOTES}

1. Of all language uses, the poetic function of language as postulated by Jakobson (1981: 22-25) is the most intricate; the musicality of poetry, especially poetry by a great master, is, therefore, the most difficult to translate.

2. For lack of a more precise word, I have to use the word "limitations" to describe the absence of the phonological features of one language in another. Strictly speaking, "limitations" is not an accurate word, since every language has its own genius, and can perform all the functions expected of it by its speech community.

3. I have used bold type in the quoted words to indicate the sounds under discussion.

4. English translation: "And in His will is our peace" (Sinclair 1971 Paradiso: 53).

5. This does not mean, however, that German is inferior to Italian in performing all kinds of verbal music. When harsh sounds are required to suggest the discordant, German is a better choice than Italian, as can be inferred from the opening of Canto 32 of the Inferno:

S'io avessi le rime aspre e chiocce, come si converrebbe al tristo buco

sovra 'l qual pontan tutte l'altre rocce,

io premerei di mio concetto il suco

più pienamente; ma perch'io non l'abbo,

non sanza tema a dicer mi conduco.... (Dante 1960: 551)

(Had I the harsh and grating rhymes that would be fitting for the dismal hole on which all the other rocks bear down I would press out more completely the sap of my conception....(Sinclair 1971 Inferno: 395)

Here Dante is indirectly admitting that the Italian language is too musical (in the conventional sense of the word) to suggest the "harsh" ("aspre") and "grating" ("chiocce"). Were the poet writing in German at the time, he would not have had such a problem, since German would have provided him with all the "harsh" and "grating" words (like "Rad" for example) he needed.

6. The relative stature of Dante and Shakespeare is well summed up by Eliot, elected by Time magazine in 1999 to be the most influential poet and critic of the twentieth century, in his classic essay, "Dante":

And take the Comedy as a whole, you can compare it to nothing but the entire dramatic work of Shakespeare....Dante and Shakespeare divide the modern world between them; there is no third.... (Eliot 1951: 264-65)

Shakespeare gives the greatest width of human passion; Dante the greatest altitude and greatest depth. They complement each other. It is futile to ask which undertook the more difficult job. (Eliot 1951: 265)

Coming from no less a poet and critic than Eliot, the judgment carries more weight than those pronounced by any other poet or critic of the twentieth century. By studying the work of two poets who have brought their respective mother tongues to a level of development any mortal could ever hope to bring, the comparison will be methodologically sounder than a comparison of two poets whose achievements are clearly unequal.

7. For the sake of analysis, the phonemes are discussed separately here. When the lines are heard, all sounds (vowels and consonants) will work together as an organic whole, making an impact that defies phonetic analysis.

8. He can, for example, reproduce the alliteration in "fillet of a fenny snake," "boil and bake," "Lizard's leg," "hell-broth boil and bubble," "mummy, maw," and "salt-sea" (my italics).

9. It should be pointed out that the translator has also deviated from the original on the semantic level. "Eye of newt" and "Wool of bat," for example, have been translated respectively as "ramarro occhiuto" 
and "vampiro peloso," which, in back translation, would mean "sharp-sighted green lizard" (Rebora 1972:343, 413) and "hairy vampire" (Rebora 1972: 367, 553), thereby shifting the focus from the part to the whole. As the semantic level is not an area to be covered in my paper, deviations like these have been left out.

10. The five Chinese characters are respectively in the first, the fourth, the third, the fourth, and the fourth tone.

\section{REFERENCES}

Arce, J. (trans.) (1968): La Divina Comedia, By Dante Alighieri, Barcelona, Ediciones Nauta.

Alighieri, D. (1960): Le opere di Dante: Testo critico della SociPta Dantesca Italiana, Seconda edizione, Firenze, Nella sede della SocietB.

Borchardt, R. (trans.) (1967): Dantes Comedia Deutsch, Stuttgart, Ernst Velag.

Cassman, V. (trans.) (1983): Macbeth, By Shakespeare, Oscar classici, Milan, Arnoldo Mondadori Editore.

ELiot, T. S. (1951): Selected Essays, London, Faber and Faber Limited.

Gmelin, H. (trans.) (1949): Die göttliche Komödie. 3 vols. 1: Die Hölle; 2: Der Läuterungsberg; 3: Das Paradies. Stuttgart, Verlag von Ernst Klett.

Huang, G. [Laurence Wong] (trans.) (2003): Shenqu [La Divina Commedia], By Dante Alighieri, 3 vols. 1:Diyupian [Inferno]; 2: Lianyupian [Purgatorio]; 3: Tiantangpian [Paradiso], Taipei, Chiuko Press.

Jаковson, R. (1981): “Linguistics and Poetics." Poetry of grammar and grammar of poetry, Vol. 3 of Selected writings, Ed. Stephen Rudy, The Hague, Mouton.

Mandelbaum, A. (trans.) (1980-1984): The Divine Comedy of Dante Alighieri: A verse translation, By Dante Alighieri, 3 vols. 1: Inferno; 2: Purgatorio; 3 Paradiso, New York, Bantam Books.

Mitre, B. (trans.) (1938): La Divina Comedia, By Dante Alighieri, Traducciln en verso, Bibloteca Sopena. Buenos Aires, Editorial Sopena.

Rebora, P., prepared with the assistance of Francis M. Guercio and Arthur L. Hayward. (1972): Cassell's Italian-English / English-Italian dictionary, London, Cassell.

Risset, J. (trans.) (1992): La Divine Comédie, By Dante Alighieri, 3 vols. 1: L’Enfer; 2: Le Purgatoire; 3: Le Paradis, Paris, G. F. Flammarion.

Saravalle, F. I. de (1891): Translatio et comentum totius libri Dantis Aldigherii, By Dante Alighieri, Cum textu italico Fratris Bartholomaei a Colle nunc primum edita, Prati, Ex Officina Libraria Giachetti, Filii et Soc.

Shakespeare, W. (1974): Complete Works, Ed. W. J. Craig, London/New York/Toronto, Oxford University Press.

Simpson, D. P. (ed.) (1968): Cassell's Latin Dictionary: Latin-English / English-Latin, 5th ed. New York, Macmillan Publishing Company.

Sinclair, J. D. (trans.) (1971): The Divine Comedy of Dante Alighieri, By Dante Alighieri. 3 vols. 1: Inferno; 2: Purgatorio; 3: Paradiso, London, Oxford University Press. 